\title{
Tax Harmonization in the EU: Insights on Political and Legal Fusion under Neofunctional Rationale
}

\author{
Shafi Ullah Khan Niazi ${ }^{1}$ \\ ${ }^{1}$ Department of Business Law \& Taxation, Monash Business School, Monash University, Australia \\ Correspondence: Shafi Ullah Khan Niazi, Department of Business Law \& Taxation, Monash Business School, \\ Monash University, Australia. E-mail: shafi.khan@monash.edu
}

Received: January 4, 2016 Accepted: January 29, 2016 Online Published: May 29, 2016

doi:10.5539/jpl.v9n4p15 URL: http://dx.doi.org/10.5539/jpl.v9n4p15

An earlier version of this article was presented at the 27th Conference of Australasian Tax Teachers Association (University of Adelaide, January 2015). The author is grateful for helpful comments provided by Professor Rick Krever and participants of the Conference. Helpful comments of two anonymous reviewers and assistance extended by Preeti Srivaastava is also acknowledged. The Australian branch of International Fiscal Association (IFA) awarded the IFA - Graham Hill Prize 2015 to the earlier version of this article.

\begin{abstract}
The traditional narrative is that direct taxes in EU remain non-harmonized since decisions in this domain originate solely from intergovernmental bargains, often exemplified as failure of legal, political and economic integration. The article reviews this conventional notion that European tax harmonization process draws truly on national-choices of Member States. The contribution does not out rightly discard national role in pooling EU-level tax mandate but rather assigns it a temporal dimension under neofunctional integration model. Considering the intergovernmental politics and members decision-making in isolation, akin to that of traditional nation-state in global arena, may create a misleading conception in EU context. European Member States might seem to be the sole political actors of EU-level tax policymaking, yet there exist other players that shape or even push national decision-making processes. The study provides a bigger-picture perspective that seeks to capture key legal, political and economic developments instrumental to the European integration project. It concludes that (direct) tax policy domain - a symbol of fiscal sovereignty of Member States and unspoken regime in EU law - is also not impervious to neofunctional political rationale and consequential processes of law-creation.
\end{abstract}

Keywords: European Union, tax politics, neofunctional politics, tax harmonization, intergovernmental politics, European integration, differentiated integration

\section{Introduction}

Given the sovereignty concerns associated with the tax policymaking, often conceived seated at the core of nation-state's fiscal autonomy, the traditional notion is that the European level tax mandate remains very limited - ascribed generally as a failure of political and economic integration in the European Union (EU). The result being that the construction of supranational EU tax mandate beyond the choices of Member States often goes unmapped. (Note 1) The study explores harmonization of direct taxes and traces processes of EU-level law-making in tax domain that may not necessarily be the outcome of intergovernmental politics or spontaneous decisions of EU Member States. The study explicitly undertakes the task to investigate the role of non-state and supra-state actors shaping or even pushing national decision-making behind the scene to create EU-level tax rules.

The contribution departs from the traditional notion that any shift in powers from Member States to the EU in an otherwise politically sensitive tax policy area is dependent solely on national choices of EU members. The approach adopted in this article draws heavily on neofunctional political model of integration developed by Haas (1958, 1964) and later refined since 1990s (Sandholtz \& Zysman, 1989; Stone Sweet \& Sandholtz, 1997, 1998; Marks, Hooghe, \& Kermit, 1996; Sandholtz \& Stone Sweet, 2013). The model explains how suprastate and non-state actors can trigger a chain of dynamic processes that have the potential to construct EU-level (tax) rules in the long run alongside and beyond intergovernmental bargains. 
Consistent with the traditional national-choice premise, a recent work based on intergovernmental politics on European taxation, for example, argues that the "limited transfer of tax authority [from Member States] to the EU exemplifies the failure of political and fiscal integration" (Wasserfallen 2014). Relying on two indicators, it illustrates how limited the transfer has been: (1) the absence of any genuine European tax source for spending of the supranational polity, and (2) taxation in Member States is not harmonized due to limited EU-level de jure competence to harmonize national VAT regimes, while direct taxation is not even mentioned under the Treaty on the Functioning of the European Union (TFEU) (Wasserfallen, 2014: 424). The reported study suggests low-tax countries perceive themselves as potential winners from tax competition in the single market - with the result that they will oppose shifting of tax authority to the EU. The national-choice thesis is then tested by investigating positions taken by heads of state at the intergovernmental conferences (IGCs) of Maastricht, Nice and Lisbon in respect of proposals to replace the unanimity principle with that of qualified majority voting (QMV) in tax legislation, a change that would lead to the abolition of national veto on taxation. The findings support intergovernmental bargaining proposition when considered in isolation. I however submit that if the findings are considered in the wider historical context of EU legal construct and political/economic integration, the limited steps to date towards tax harmonization may be viewed as an evolutionary phase of the European integration project rather than its complete failure.

The intergovernmentalist approach generally assumes the position taken by each Member State on tax legislation at the IGCs as a measure of national bargains and the consequent findings show that: (1) "low-tax countries were more likely to oppose tax harmonization" (Wasserfallen, 2014: 426-429) and (2) "the support for EU-wide tax harmonization dropped to a record low" during the Lisbon negotiations (in 2004) since the Eastern enlargement (Wasserfallen, 2014: 430-431). (3) In the post-Euro era, the intergovernmental scholarship expects restructuring in politics of tax centralization - predicting that while the Euro may lead to a European tax source, it would not impact tax harmonization (Wasserfallen, 2014: 431-432).

In achieving an efficient, smart and sustainable single market, the need to have a degree of neutrality in national tax policies through adoption of integrated fiscal approaches at EU-level is undeniable (Smith, 1996: 8; Khan Niazi \& Krever, 2015: 459). On the other hand, however, at first glance, there is a little room to disagree on the lack of (express) textual mandate to legislate supranational tax rules under the EU law. For example, in the initial phase beyond three decades (1958-1990), there existed no substantive legislation on direct taxation. (Note 2) Furthermore, since 2003 the EU has adopted little substantive legislation in this policy area. (Note 3) From this and what follows from the fore-going intergovernmentalist findings, at least two questions in EU political and legal studies arise. (1) Whether the tax policy area is an outlier to the neofunctional political approaches developed by Haas and successors that explain integration as a process of sectoral "spillovers" by which national authorities gradually but persistently migrate to EU-level. (2) Whether taxation is a domain where the general legal scholarship on mobility and growth in EU competences (e.g., Tizzano, 1981; Craig, 2002) fails to apply.

The current study investigates these questions and seeks to explain whether tax harmonization exemplifies failure of European fiscal integration. In doing so, the findings reported for and against QMV in taxation (Wasserfallen, 2014: 429-431) are reviewed under neofunctional logic of integration (Note 4) and then also tested against additional data. In attending the questions raised by this study, the focus confines to harmonization of direct taxes of Member States. The task is challenging and complex since direct taxation is (a) a terrain of "high national politics", (b) a least harmonized tax regime in the single market, (c) a policy area lacking express EU mandate under the TFEU and (d) a domain requiring unanimous consensus of Member States for EU-wide legislation. Thus it may not be unrealistic to observe that integrative outcomes in direct taxation can be presumed as a threshold regime to demonstrate transnational political processes theorized under neofunctional modes. The findings of this study do not suggest that taxation is impervious to neofunctional processes. Nor do the findings indicate that harmonization in this policy sector has utterly failed within the EU as often indicated by scholarship drawing truly on intergovernmental bargains. Rather the results demonstrate that politics of European tax integration is an ongoing evolutionary process having causal links rooted in the neofunctional theory.

The article proceeds as follows. Section 2 explains neofunctional framework as a method of European integration that is central to political and legal analysis to follow. Section 3 then explores whether EU-level authority in tax policymaking is impervious to the neofunctional theory that conceptualizes law-making processes beyond national choices. For this purpose, the study employs neofunctional tools to the data on QMV in taxation at the IGCs analysed in earlier studies to argue EU as a case of failed political and economic integration. Section 4 extends the analysis in question to other testable issues and captures the bigger temporal picture of neofunctional construct in harmonization of EU direct tax regime. Section 5 argues on a possible neofunctional legal-political kinship in European tax policy area. Building on this argument, this section also 
evaluates potential impacts the currency union may have in the long run on tax harmonization in the Eurozone. The article finally concludes in Section 6 with a brief summary of the findings.

\section{European Integration and Neofunctional Theoretical Framework}

This section explains how the neofunctionalist framework, employed in the sections to follow, theorizes the overall process of European integration. However, first I present brief contextual distinctions to provide broad insights into the two leading approaches to integration. Scholarship on intergovernmentalism and neofunctionalism demonstrates largely as contrasting approaches to creation of EU-level rules and European integration. Both theories date back around the founding periods of the EU polity; however, they have been considerably updated and refined in the later periods (on intergovernmentalism, see, e.g., Moravcsick, 1993, 1995; Garrett, 1992, 1995; on neofunctionalism, see, e.g., Stone Sweet \& Sandholtz, 1997; Sandholtz \& Stone Sweet, 2013).

Concisely, intergovernmentalists claim EU as a product of intergovernmental bargains in the international political regime. They assert that national choices drive the integration processes with no significant transfer of national powers to EU-level beyond the preferences of Member States. Drawing from nation-state perspectives, they explain the European integration largely in terms of true intergovernmental bargains.

In contrast, the neofunctionalists theorize construction of today's "federal-like" polity, from a six-nation international organization with limited powers in 1957 (Treaty of Rome), driven by processes beyond national choices. They posit European rules and integration as an outcome of dynamic processes which occur over time as activated by transnational exchanges that account for migration of powers from national governments to the EU-level. Stone Sweet and Sandholtz (1998: 9) propose a theoretical model in terms of a continuum on governance in the EU. In this model, they do not altogether discard intergovernmentalism from the integration continuum but rather accept it as the starting point akin to the phase when the organization was founded. Figure 1 depicts this proposition in a continuum and considers the temporal elements as a measure of growing EU integration discussed as follows.

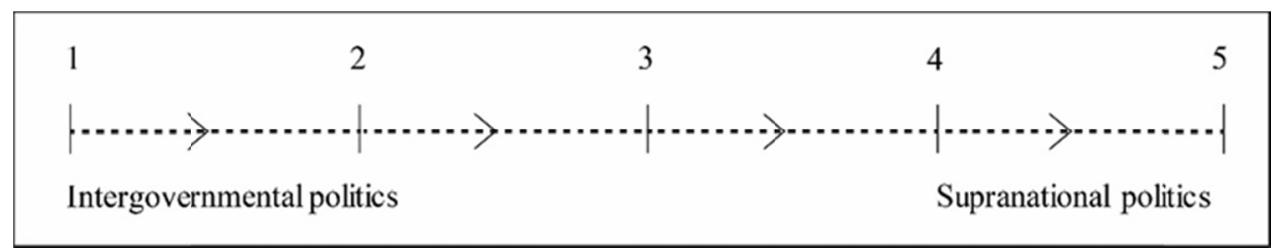

Figure 1. Continuum of Politics and Law in the EU (Stone Sweet \& Sandholtz, 1998: 8)

Sandholtz and Stone Sweet (2013) present an updated account of neofunctional framework to describe the underlying logic of European integration. They explain three elements integral to this framework. (1) Foremost is the emergence of a "transnational society" having cross-border aims and interests. The creation of transnational society is effectively the motor of the neofunctionalist theory. The society, in particular, its non-state segment of "transactors" comprising firms, groups and other players benefitting economically from the transnational exchanges are the expected produce of the fundamental freedoms and common market notion. (Note 5) The transactors however face diverse national rules across the European market that impede or add cost to their activities. This in turn triggers the need for supranational policy regimes to counteract the national laws in those policy areas which impede or add cost to their economic activities. As the transactors' activity increases, so does the "functional demand" to have supranational rules across the single market. To overcome additional costs and settle disputes caused by diverse national rules, the transactors and their lobbyists respond by: (a) exerting pressures on their national governments to gain favourable outcomes; (b) approaching the national courts to enforce their rights guaranteed under EU law - paving the way for increased referrals to the European Court of Justice (ECJ); and/or (c) generating activities at the Commission-level for pro-integration initiatives to reduce cross-border costs. (Note 6)

Drawing from Haas' thesis, Sandholtz and Stone Sweet (2013) theorize that pro-integration rules so achieved under the neofunctional mechanism thus minimize cost of cross-border transactions and foster further transnational economic activity. In due course, the (raised) cross-border transactions find new obstacles in the same or related policy areas, and push the reconstruction of a similar loop to repeat the pro-integration processes. The transaction-motivated dynamic mechanism of actions thus further deepens the integration process in a particular policy area or widens ("spills-over") to another policy area or group of related areas, and so on. The 
creation of functional demand of transactors as a part of the first ingredient of neofunctional theory is also central to our key analyses following this section.

Besides transnational society, Sandholtz and Stone Sweet (2013) also consider two other elements of neofunctionalism vital in conceptualizing the holistic framework of the theory. (2) The second neofunctional ingredient is "supranational organizations" or EU organs (European Commission and ECJ) and their specific roles in constructing supranational governance. The EU organs have considerable authority which might not necessarily be influenced by Member States and thus have the potential to produce policy outcomes that otherwise may not be achievable solely through intergovernmental bargains. (3) The third dynamic constituent of the theory, "institutionalization", has been postulated as a recurring integration process that creates new legal rights for transactors pursuant to case law and legislation produced by the functional demand of transnational economic activity. As a result, quantity of precedent and legislation grows paving the way for enhanced dispute resolution at the supranational level. In addition to theoretical framework, neofunctionalists also provide empirical evidence which maps the developments of EU integration over time (e.g., Stone Sweet, 2004).

\section{Neofunctional Politics and Tax Harmonization in the EU}

The section explains how transnational economic exchanges and the consequential rise in (functional) demand, the motor of neofunctional model, impact transnational politics in the context of tax-rates. The transactors who aim to generate gains (profits or incomes) liable to taxes may face cross-border obstacles (additional costs) in the form of diverse national tax rules. For precision, the subclass of transactors involved in gaining transnational (taxable) profits is termed as gainers in remainder of the article.

The costs to gainers may originate from a range of asymmetric domestic policies across the national borders which impede profit maximization. In terms of varying costs incurred on cross-border income generation, the gainers may also face higher tax bills in certain jurisdictions of the single market comprising heterogeneous tax regimes. The additional tax bills (obstacles in neofunctional terms) to gainers may arise at least at three levels of heterogeneity in national tax codes: tax-rate (Issue-1), tax-base (Issue-2) and double taxation (Issue-3). Issue-1 remains entirely non-harmonized in EU. Issue-2 is also not harmonized; however a part of it remained the focus of debate for almost one decade before the first-ever substantive draft legislation on a common consolidated corporate tax base (CCCTB) was presented by the European Commission. The draft still remains on a high priority of the Commission tax agenda with its pragmatic version being re-launched in 2016. (Note 7) On Issue-3, certain legislative instruments on abolishing specified forms of double taxation are in force (Note 8) albeit insufficient to cope with the diverse array of possible situations. (Note 9)

Of these three issues, the national-choice approach operationalizes the theoretical argument of intergovernmental bargains generally through focus on tax-rates (Issue-1). The intergovernmentalists view the tax-rate issue through a national political lens with a focus on tax competition among members to win revenues and investments. In this section, I restrict the analysis to Issue-1 while the remaining two issues are attended later.

\subsection{Analysing the Findings Based on Intergovernmental Politics and Tax Harmonization}

According to the national-choice model, Issue-1 draws purely from the interests of nation-states in the context of raising higher revenues in tax competition within the political economy framework. The intergovernmental work tests this hypothesis through quantifying probabilities on preferences of national governments to adopt QMV in taxation at the Maastricht, Nice and Lisbon IGCs (Wasserfallen, 2014: 421, 428-430). From this, the readiness among the national governments to replace the unanimity requirement (surrender of veto) with that of QMV on tax matters is identified. The core thesis is founded on the premise that low-taxing Member States (revenue winners) would prefer to retain veto in taxation compared to high-taxing Member States (revenue losers).

When tested support for QMV (as dependent variable) at the IGCs against the ratio of total taxes to gross domestic product (GDP) together with the national top corporate tax-rate (as explanatory variables), intergovernmental findings demonstrate that Member States with lower corporate tax rates were less likely to support QMV in tax matters (Wasserfallen, 2014: 428-429). And tax competition has increased pursuant to the enlargement from EU-15 to EU-25; the extent of the split between supporters and opponents of QMV also grown deeper (Wasserfallen, 2014: 430-431).

\subsection{The Other Side of the Tale}

The analysis based on national-choice view correctly predicts the empirical results of the experiment; however, its underlying reasoning is, in part, problematic. The supposition that Member States operate out of pure self-interest similar to traditional nation-states in the international arena may fail to take a fuller account of the episode in the EU context. The thesis that national preferences in isolation explain all dimensions of European 
integration is but one side of the story. Regional integration is not immune from external influences as it does not take place in vacuum (Caporaso \& Keeler, 1995: 35). Nor is EU integration merely the product of momentous ("one of stop-and-go") national decision-making (Stone Sweet \& Sandholtz, 1997: 307). In assuming that these are the momentous national decisions that explain the pooling of EU-level (tax) mandate in isolation, one may lose sight of some of the crucial underlying rationale of European construction. The holistic approach adopted by neofunctional methodology appreciates the temporal elements and logic of dynamic processes of (tax) integration in the EU as explained below.

In neofunctional terms, gainers may find high-taxes as obstacles to their transnational undertakings, while the opposite might be true for low-taxation. Hypothetically, one could thus fairly contend that, other things being constant, no or low cost would generate no or low consequential demand for tax harmonization in jurisdictions with low-taxes. In high-taxing jurisdictions, on the same rationale, increased costs or barriers to profit maximization may prompt a gainers demand for low-taxation. In this framework, neofunctional modes predict the same outcomes as do the intergovernmental but for different reasons as illustrated below.

Low-taxation might not necessarily be the outcome of solo flights stemming from the heterogeneity of competing states. Struggle towards low-taxation in the EU is also attributed in part to the freedom of capital mobility in the region (Kumar \& Quinn, 2012: 9). Removal of obstacles to capital and investment may also accelerate tax competition. A segment of EU tax scholarship has labelled part of such acceleration in tax competition as an "integration effect" onset by the single market agenda (Genschel, Kemmerling, \& Seils, 2011: 588). This argument accords with the outcomes produced by transnational society in EU theorized by neofunctionalists. If this argument holds, one can posit that the "race to the bottom" in the EU should be noticeably advanced than that in other regions or the OECD nations. This narrative draws on the thesis that in $\mathrm{EU}$, unlike in other countries or regions, the race to the bottom is driven by national revenue considerations as well as the integration effect of the single market. That is, the gainers demand for non-tax barriers are already optimally met by EU commitments to free capital mobility and other fundamental freedoms. Accordingly, studies have suggested a relative high level of tax competition in the EU (e.g., Genschel et al. 2011) and that foreign direct investment is also more sensitive to taxation in EU than in the rest of the world (Feld \& Heckemeyer 2011). Regional studies on corporate taxation also indicate that the EU, since 2000, has had the lowest median regional tax-rate across the globe (Kumar \& Quinn, 2012: 25).

The second finding based on intergovernmental bargains, as discussed in the start, refers to the extended cleavage between the Member States for and against QMV in taxation in the post-enlargement episode. This expanding divide also, at least in part, correlates to the neofunctional reasoning as explained below.

\subsection{The Rationale behind Enlargement Correlation}

The biggest-ever accession to EU took place on May 1, 2004 when ten new members joined - enlarging the EU-15 to EU-25. The study drawn on national-choice approaches for the period immediately following the accession round finds a sharp divide between the members over adoption of QMV to legislate tax rules. This approach attributes the growing divide to national preferences of low-tax countries to retain veto on tax legislation in the enlarged single market (Wasserfallen, 2014: 430-431).

The newly acceded jurisdictions were significantly younger than the pre-existing single market. In 2004, the new accession indeed could be described as in an embryonic phase of integration - and their integration status could be compared to that of the founding members in the initial period of the common market. Undoubtedly, today's legal supremacy and institutional force of EU organs remain incomparable between the foundational phase in 1957 and the accession episode in 2004, yet the crucial absence of exchanges, transactors (gainers) and their causal linkages to market processes are possibly analogous. (Note 10) A pertinent instance to that effect could be cited from the positions taken by the members of the European Parliament (MEPs) at the time of adopting resolution on the draft CCCTB legislation in 2012. The "MEPs from new member states voted significantly more against the [CCCTB] proposal than MEPs from old member states" (Roggeman et al. 2015: 19). It can therefore be argued that on the bi-polar continuum of intergovernmental and supranational politics (Figure 1), the new entrants would lag behind the old (EU-15) members, and thus newcomers could be mapped rather towards the intergovernmental pole. On corporate tax calculus, one could plausibly conceptualize the formation of two distinct groups: the older EU-15 towards the right pole of the continuum (Figure 1) and the newer EU-10 towards the opposite pole.

Genschel et al. (2011: 596-597) take an interesting note of the dynamics of preferential tax regimes in the EU prior to the 2004-accession round. They notice that prior to 2004, the Commission pursuant to state aid prohibition (Article 107 TFEU) identified 30 special regimes in the tax statutes of new members which they 
were required to abolish. Curtailing preferential (reduced) tax regimes might also fuel general tax competition (Keen 2001). For example, Poland, the Slovak Republic and Cyprus unprecedentedly slashed corporate tax-rates by almost one third around the accession times in 2003-2004. (Note 11) Thus the older and newer EU jurisdictions have in part distinct underlying theoretical rationale when it comes to (tax) harmonization and, in the short to medium run, need to be viewed through separate lenses of political and economic integration.

In the foregoing analysis of enlargement, I demonstrated that the cluster of ten new members (an EU subset) in 2004 might behave in a rather more intergovernmental mode at their embryonic phase compared to the remainder common market. The outcome being that seemingly the deepest-ever cleavage was recorded between members and reported as the lowest-ever support for QMV in taxation (32\%, Table 1: row A). This decline however offers a crucial puzzle. Whether the enlargement undermined the effects of transnational economic activity and consequential demand for integrated (tax) rules accumulated over time in the older jurisdiction (EU-15)? If no, how could one explain and track that demand created over time in the pre-established market following the mix-up caused by the accession episode? One plausible response to these inquiries lies in the following analysis.

Table 1. "Share of support for QMV in taxation in the Maastricht, Nice and Lisbon IGCs"

\begin{tabular}{cccc}
\hline & $\begin{array}{c}\text { Maastricht } \\
(1991)\end{array}$ & Nice & Lisbon \\
& 50 & $(2001)$ & $(2004)$ \\
\hline (A) Share support (\%) & EU-12 & 47 & 32 \\
(B) Total Member States & 6 & EU-15 & EU-25 \\
(C) Share support (BxA) & 7 & 7 \\
\hline
\end{tabular}

Source: Wasserfallen (2014: 431); Row-C added by author

The quantitative analysis built on the theoretical approach drawing truly on national bargains indicates a stark decline in support for QMV in tax matters (Table 1). The support for QMV in taxation was exactly $50 \%$ in the Maastricht negotiations; it dropped slightly to $47 \%$ in the Nice, and then declined sharply to $32 \%$ during the Lisbon negotiations. The decline in support over time in percentage terms on-the-whole is one possible way of explaining the enlargement effect (Table 1: row A). This trend however can also rationally be interpreted in another convincing way. If the share support for QMV in percent points is converted into the (theoretical) number of Member States at the three IGCs, it shows that support never declined (Table 1: row C). Rather it is indicative of a slight but consistent periodical rise in the number of members supporting QMV to enact tax rules.

It follows that the rise in support is also comparable to the outcomes generated over time through the impulses of functional demand accumulated largely in the pre-established niches occupied by the transnational society representing gainers. When weighted in aggregate percentage terms, this rising demand is masked by the growing membership of the EU. Instead of presuming that the enlargement produced a spontaneous (biggest-ever) failure in tax harmonization, a more nuanced analysis on the varied time scale, as theorized by the neofunctional continuum (Figure 1), would explain the additional underlying logic of European integration. (Note 12)

After tax-rates (Issue-1), I turn to the tax-base (Issue-2) and double taxation (Issue-3) as potential impediments to the transnational income generation activities and their interplay with creation of binding (tax) law under neofunctional thesis.

\section{Neofunctional Politics at Work in Creation of Law and European Tax Regime}

In examining the remaining two issues, this part provides crucial insights on causal connections between neofunctional processes (gainers demand, spillover, quest for integrated rules) and creation of EU-level (tax) mandate beyond national bargains. In order to establish the causality, I rely on some of the conventional developments of EU organs in the past three decades. I nevertheless recast the results of these developments and pass them through the neofunctional apparatus to seek findings of this study. The analysis considers tax burdens to gainers from diverse tax-bases and double taxation (Issues-2 \& 3) alongside since both have analogous legal characters as illustrated below.

\subsection{Searching Proxies to Analyse Issues-2 and 3}

Tax-bases are not as visible as tax-rates (Genschel \& Schwarz, 2011: 352). Unlike tax-rates which are easily 
identifiable digits, and so are their outcomes (potential costs), tax-bases carry multiple legal connotations in taxing jurisdictions. To evidence the creation of demand, if any, spurred by neofunctional processes against impeding tax-bases and double taxation of profits thus requires a proxy. This requirement distinguishes the argument on Issues-2 \& 3 from that on Issue-1 since the latter being measurable cost/obstacle did not require any proxy.

Transnational activities generate dynamic processes that tend to produce enforceable instruments for harmonization of national laws and policies. It may therefore be a worthy notion that in order to determine the application of this theory one may like to assess and quantify the existence of one of the end-products (instruments) manufactured during the neofunctional processes. To search the demand-driven end-products manufactured in the model, I revisit the neofunctional methodology within the EU legal framework in the form of a schematic illustration.

Figure 2 presents this illustration. It explains the formation of at least three end-products triggered by transaction-led processes which generally produce EU-level rules for single market. The three end-products (integrative outcomes) can be: (a) ECJ rulings, (b) activation of Commission-level (legislation-related) functions and (c) attaining integration of national laws in compliance to infringement proceedings. Since the three outcomes, to varying degrees, are either the product of, or are impacted by the transactors' demand for a level playing (harmonized) field, one or more of the outcomes therefore may suit as proxy for our investigation. Recent neofunctional scholarship has devised a method to quantify the correlation between the intensity of transactors' activity with the frequency of related cross-border disputes referred to the ECJ (Stone Sweet, 2004). It is worthwhile, therefore, to investigate activity at ECJ-level to capture and examine the dynamics of gainers demand for EU-level tax rules.

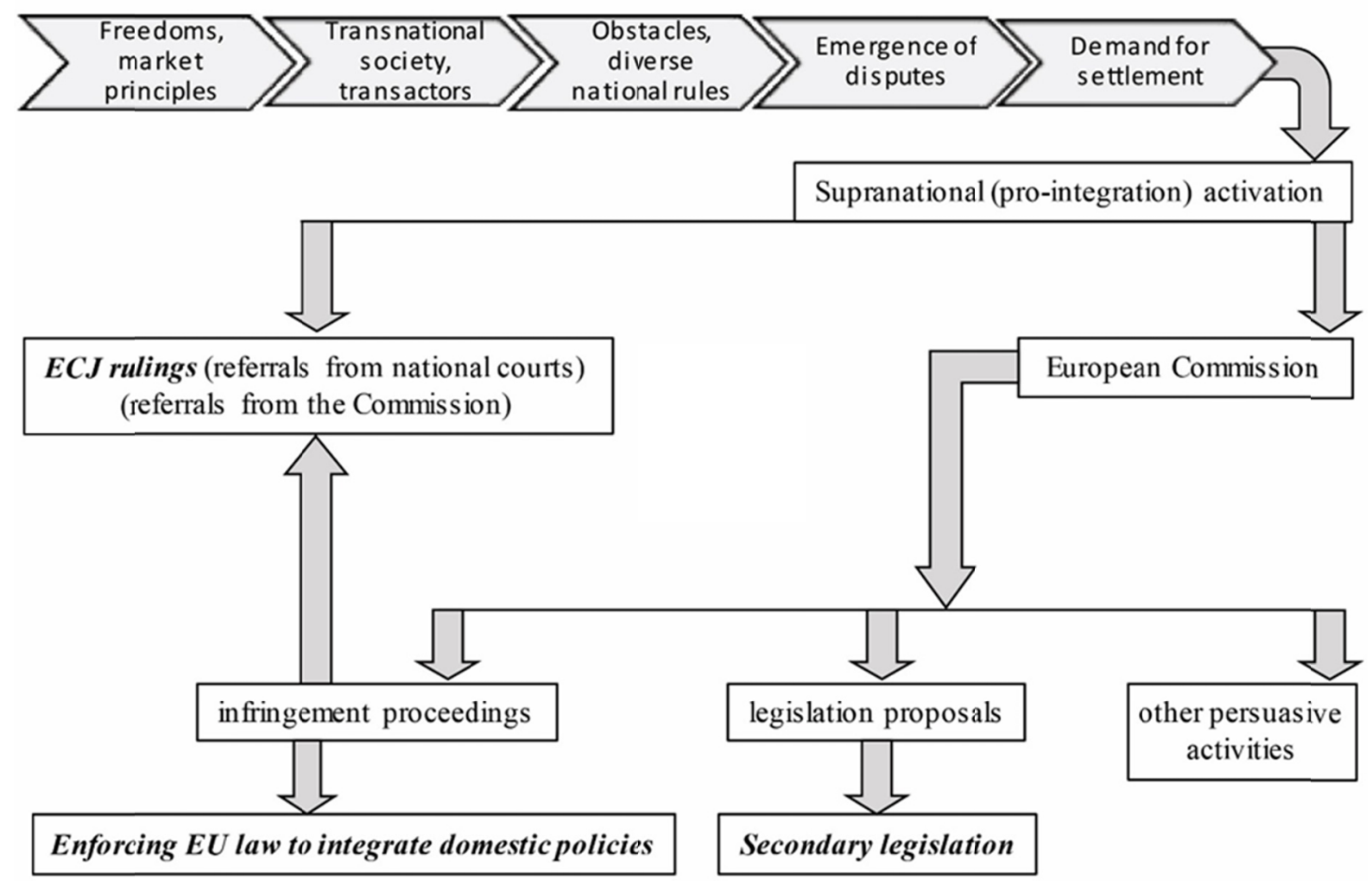

Figure 2. Schematic Flow Chart Depicting Causal Linkages between Neofunctional Political Processes and Production of Binding Law in EU

\subsection{Activity at the ECJ as an Expression of Gainers' Demand}

Tax disputes at the ECJ are predominantly initiated by private litigants (gainers) and referred by national courts (Article 267 TFEU). Litigation at ECJ may also be consequential to the proceedings initiated by the European Commission against the infringing national (tax) laws (Article 258 TFEU). The gainers are not directly party to 
Commission-led tax referrals. Yet practically speaking, the Commission referrals too are not only aimed at mitigation of gainers costs but are also at times the product of gainers influence. (Note 13) A segment of legal scholarship is though critical of the quality of ECJ rulings in the direct tax area (e.g., Graetz and Warren, 2006, 2007; Kemmeren, 2008; Schon, 2015); the issue at hand however largely targets the quantity of disputes (to measure gainers demand). The frequency of disputes at the ECJ is thus used as a measure of the intensity of demand for EU-level dispute settlement or integrated tax rules on Issues-2 \& 3. Building on this framework, I quantify gainers demand for homogenous policies in the single market through their pursuits to settle transnational disputes on Issues- $2 \& 3$ as manifested by frequency of tax referrals to the ECJ. These referrals to ECJ may originate from two sources as shown in Figure 2. To demonstrate the causal relationship between the quantity of transnational disputes and increasing demand for (tax) integration, I first present the litigation data specific to the policy area of direct taxes and then analyse it using the neofunctional tools.

Figure 3 shows all direct tax disputes referred to the ECJ until 2014. It identifies two trends in direct taxes. First, a temporal growth in the functional demand of gainers as illustrated by increasing levels of private litigation (Article 267 referrals) as well as increasing pressures from private actors on Commission (Article 258 referrals). Second, a belated start of tax litigation (1983) in the single market and then a remarkable surge of tax disputes since the mid-1990s. The rise in tax litigation is a significant indication of neofunctional spillover attained in the tax policy domain by adequate prior transnational activities of gainers. (Note 14)

Despite the fact that the foregoing analysis provides some convincing causal connections between the neofunctional integration logic and the quest to have level-playing (harmonized) rules, a crucial puzzle yet seeks response. The European polity came into existence 1958; however hardly any demand or spillover is evident in our investigation until the 1990s (Figure 3). Why did it take so long for neofunctional processes to induce spillover in the tax arena? The answer to this crucial puzzle is sought in the following segment.

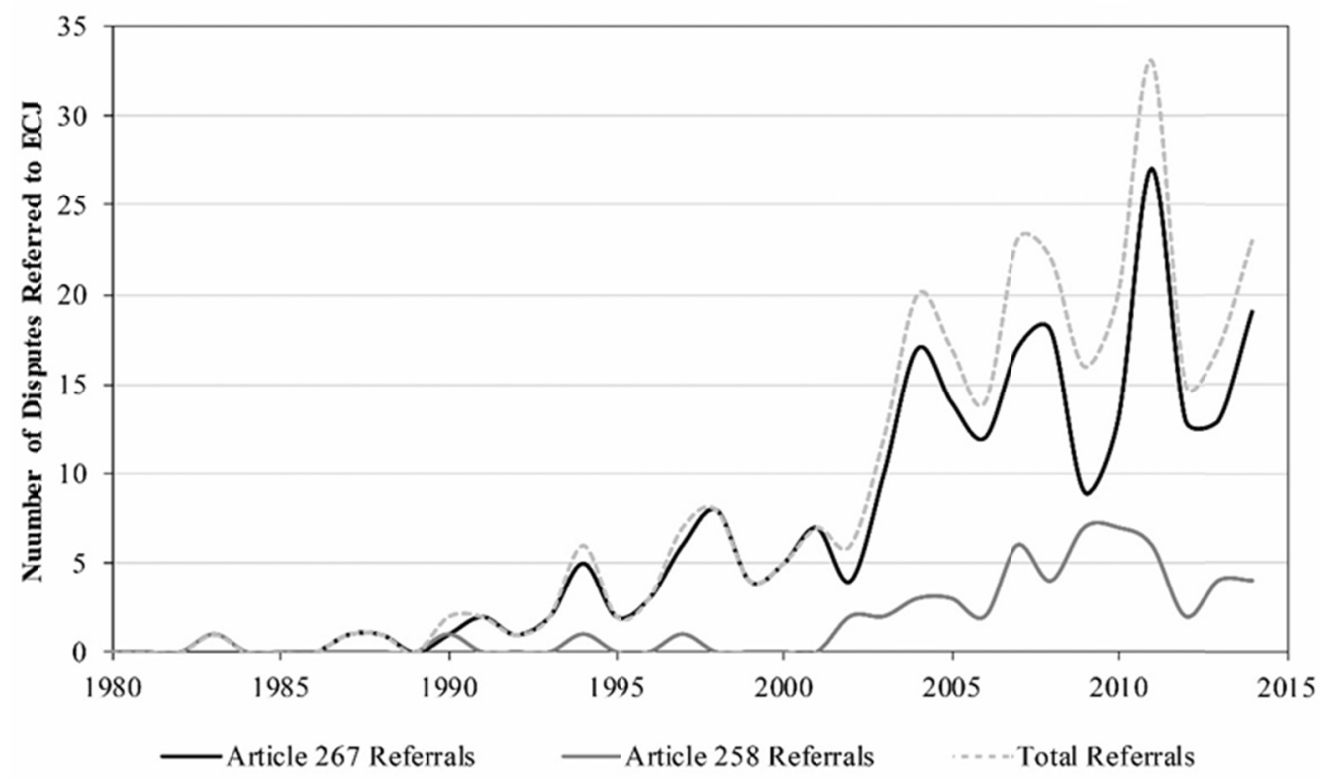

Figure 3. Rise in Demand Indicated by Growing Trend in Number of Income Tax Disputes Referred to ECJ 1983-2014 (Data based on Directorate-General of Taxation \& Customs Union, 2015; Schaper, 2014a: 237)

\subsection{Spillovers, ECJ and Construction of Binding Law}

Scholarship on the application of neofunctional modes to direct taxation is hardly existent. On the other hand, an intergovernmental response to this puzzle would be obvious, that is, the stronger opposition met from national governments in an area rooted in their fiscal sovereignty and taxing powers. Consistent with neofunctional literature, I do not out rightly discard national sovereignty from the integration calculus but rather seek to keep it in the right perspective. Undoubtedly, national preferences for and against integration across different policy areas incidental to the single market may vary. This can certainly have impact on integrative measures and policy developments, particularly in areas of core state powers or "high politics" (Schimmelfennig, Leuffen, \& Rittberger, 2014). I however submit that while the national politics can impact the pace of integration, the policy areas incidental to the single market are not impervious to neofunctional processes in the long run. The national 
impacts cannot halt the accumulating societal or transactors demand forever. I contend that there is also an additional factor, drawn from neofunctional logic which accounts for the belated spillover in direct taxes explained as follows.

In direct taxation, it is persuasive to argue that bilateral tax treaties would have remained the first port of call for gainers demand of mitigating tax burdens on transnational activity. (Note 15) In the early phases of a relatively less integrated market, the documented and laid down procedures for mitigating transnational burdens under the public international law (tax treaties) are likely to outsmart the unspoken EU powers in the same policy area. At this stage, the tax-spillover is not altogether contained but rather its impact is neutralized by supra-state instruments of public international law.

In temporal terms, as transnational activities gain momentum and the market advances, bilateral market-tax-solutions offered by tax treaties under traditional international law become unsustainable to the imperatives of an otherwise highly integrated single market. As a result, supranational rules beyond the scope of bilateral tax agreements become indispensable. On the other hand however, the implicit constitutional power on direct taxation yet entails little legislation. The national fiscal sovereignty concerns in tax domain may add further complexities and sloth to legislative initiatives. For want of optimal (legislative) guidelines on impediments faced by gainers, such policy domains are ultimately bound to generate disputes beyond those tackled by the tax treaty tools. At this critical stage, the market forces prefer to push fast-track dispute resolution mechanism instituted for the single market by exploiting freedoms and non-discrimination principles at ECJ-level instead of waiting for the sluggish legislative processes marred by the unanimity rule. Hence the gainers demand to settle their transnational disputes spill-over beyond the national bargain framework (under public international law) into the spheres of European legal framework. The surge in demand to settle dispute is the front-runner of the processes leading to spillovers. Both these elements of neofunctional model in turn have a strong nexus with the construction of soft and hard EU law. First, attaining a degree of rulings-based symmetry in transnational rules for the benefit of gainers is inevitable (e.g., Schaper, 2014b) notwithstanding the criticism on specified areas of Court's jurisprudence.

Second, ECJ decisions on gainers disputes also activate other processes. The Commission, for example, pursuant to increasing tax case law, committed itself to a proactive search of executive and legislative functions in the direct tax domain. (Note 16) Moreover, the Court-led dispute resolution activities may also impact other national and supranational actors. For example, in the absence of legislative guidelines, ECJ rulings in tax regime may in some cases constrain national tax policy-making. This is because judicial harmonization can quash discriminatory or anti-single-market (national) tax provisions but cannot synthesize alternative tax rules (McLure, 2008: 408). Big achievements such as harmonized tax bases are achievable only through supranational policy-making (Graetz \& Warren, 2006: 1223). Since no national government would like to see its tax base eroded by ECJ decisions (Radaelli \& Kraemer, 2008: 319), states might therefore respond reactively to the Court decisions by recourse to harmonized tax policies (McLure, 2007: 143). Thus, the unforeseen proscriptive court rulings against national tax provisions may also incentivize members to recourse towards more predictable prescriptive EU-level (tax) policy-making. Accumulation of case law facilitates the consensus-building process amongst Member States for legislation (Genschel \& Jachtenfuchs, 2011: 303 citing Aujean, 2007) and thus in the long run paves the way towards the construction of legislation-based tax regime.

\section{Variation in Political Demand, Differentiated Integration and Prospects for Tax Harmonization in EU Subsets}

Finally, I review the intergovernmental approach to tax centralization in the Eurozone that predicts a space for future European source tax but discards prospects for tax harmonization. Section 3 documented insights on tax-rate-specific variation and the effect of policy divide caused by the 2004-accession between the old and new sub-systems of the EU (EU-15 and EU-10). Further analysis of the accession episode however underpins an additional but wider-level puzzle that lies in the question on how variation in functional demand correlates to neofunctional dynamics. From EU-6 in 1957 to date EU-28, the polity is an outcome of a series of six accession rounds at different points in time. Drawing from our earlier analysis on the 2004-enlargement episode, one can posit that various groups of Member States may have different levels of societal and transactors demand for integration which is dependent, amongst other factors, on their age and volume of transnational activities. (Note 17) In direct taxes, for example, out of the total number of direct tax cases referred to ECJ (Figure 3), two-third relate to a subset comprising the six founding members. (Note 18) Notwithstanding the demand-level in its jurisdiction, each new member on the other hand enjoys full legislative powers in the Council including veto on taxation from the day one it accedes. Such disparity may pose severe challenges to the consensus-building process to legislate binding acts, particularly in policy areas requiring unanimity such as taxation. Hypothetically, 
a member (in unanimous voting) or group of members (in QMV) where demand and spillovers are inadequate to push the integration processes can undermine certain clusters of functional demand accumulated elsewhere in the enlarged single market. The supranational law-making process is thus faced with an impasse: How to capture and utilize the synergies of demand on political and legal integration which have the centripetal sentiment but lies in unevenly scattered clusters across the EU?

The authors of EU law perhaps had initial insights on this dilemma in the 1990s. Following the 1995-enlargement round (EU-12 to EU-15), a treaty provision was introduced in an attempt to funnel the scattered pro-integration sentiment into differentiated secondary law. Once sufficient level of societal demand in a given subset is channelized into an integrated (cost-reducing) policy, the laggards could catch up later at an optimal stage determined by demand of market forces. The case of Schengen Agreement, when a cluster of five members (in the then EU-10) joined hands in the mid-1980s to create a borderless area, later followed by others, (Note 19) would have also remained as a success story to the drafters of EU law. Accordingly, a window of opportunity was crafted in EU constitution under the Treaty of Amsterdam 1997, (Note 20) which was further refined through enhanced cooperation regime under the Nice revision. (Note 21) This formally authorized a subset of minimum eight (currently nine) members to initiate legislation in a policy area within their jurisdictions if an EU-wide law is otherwise not attainable through unanimous or QMV measures. (Note 22) McLure (2008: 416), long ago, suggested enhanced cooperation as a future key to "breaking the legislative logjam" in tax harmonization.

With this argument on nexus between law and neofunctional thesis, I refer back to the analysis regarding tax centralization within the Eurozone offered by national-choice scholarship. The key points of that scholarship on the restructuring of politics of tax centralization after the creation of the European Monetary Union (EMU) are summarized in three main points (Wasserfallen, 2014: 431-432). (1) Unlike eastward enlargement that led to a decline in tax harmonization, the EMU creates incentive for pooling of EU-level tax authority. This shift in authority to the EU has however been predicted for the European tax source, not for the single-market-driven tax harmonization. (2) The surrender of national monetary autonomy was a momentous decision of Member States. Put differently, it suggests that integration of EU monetary policy was a product of spontaneous national choices to integrate economic and fiscal policies. (3) Induced by the Euro-crisis since 2009, actions in tax domain may not target the entire EU but rather be "shaped by the interest cleavage between the members of the eurozone and the non-eurozone countries".

These arguments of intergovernmental perspective provide crucial insights into the contextual as well as prospective actions on EU-wide political, legal and fiscal integration. A neofunctional analysis however reveals that the three arguments so summarized seem right on some counts but for different reasons. The analysis based on the intergovernmental reasoning often captures the outcomes and attributes those to the most visible and immediate available actors, the national governments, often losing sight of the holistic picture that also includes other players and the single-market-driven forces shaping national decision-making. While intergovernmental arguments pay tribute to the visible episode of exercise of national choices that takes place at the end of the day, they largely ignore the factors shaping these choices, or even pushing them to act in the way as posited earlier. The points summarized below seek to bridge this gap and present a holistic rationale behind the possibility of restructuring of EU tax mandate in the post-Euro regime.

First, the analysis on possible enhanced fiscal integration in the Eurozone is reasonably appealing since the monetary and fiscal policies, sister policy domains in a single economic market, can impact each other. On capturing the imperatives behind this premise, the intergovernmental stance however follows but only part of the story. Dual monetary system may tend to generate two levels of gainers functional demand for cohesive fiscal policy. The Euro-led developments may thus generate diverse demand-levels for economic and fiscal integration within the two EU sub-systems (Euro and non-Euro areas).

Second, the surrender of national currencies (a symbol of sovereignty) was not a spontaneous national decision confined solely to members but rather also impacted by external factors and market spillovers beyond the truly static national preferences (Sandholtz, 1993). Conceiving the emergence of EMU in a void confined truly to politics of nation-state paradigm is an over-simplification. The process of integration of national currencies had a "life" and evolution of its own in terms of progressive developments of the common market (Cameron, 1998).

Third, the construction of supranational mandate based on EMU may not remain contained to the single element of EU fiscal policy such as European tax source. Fiscal regime is not a water-tight phenomenon to remain insulated from the surrounding spillovers and the growing demand for harmonized tax rules. Having a common origin based on neofunctional reasoning, both are likely to go hand-in-hand. Rather, if the argument so offered 
about the Euro-based shift in EU-level mandate in favour of a European tax source holds, it may further fuel the harmonization of national taxes. Experience has proven that existence of a central-level tax is in itself a strong force in bringing symmetry to the sub-central tax codes. The literature on politics of state-federation tax harmonization in the United States (McLure, 2008: 423-424; Duncan \& McLure, 1997) and Canada (Mintz, 2004) shows that states are strongly encouraged and even constrained (Hellerstein, 2008: 151) to conform their taxes to federal taxation.

\section{Conclusion}

Deviating from the traditional notion that decisions on tax matters originate solely from the national choices, the study contributed to the literature on construction of EU-level tax governance beyond national bargains. Instead of discarding the role of national interests in shaping EU-level tax authority, the contribution sought to assign it a bigger-picture temporal framework in the EU integration project. Considering national decision-making and tax competition agenda in isolation, akin to those operative between the conventional nation-states in the global arena, may often be misleading conception in the EU context. While national governments may appear sole determinants of policy formulation, neofunctional framework captures causal mechanisms through a host of actors/factors that practically shape the national decision-making behind the scene, and taxation is no exception.

In short to medium term, the 2004-accession episode might appear to send a message of increased cleavage between the economic interests of old and new EU subsets but a larger picture of European integration is embedded in the neofunctional rationale. The study indicates that the apparently increased heterogeneity such as the one caused by the 2004-accession round indeed does not undermine the pre-generated demand for legal and fiscal integration. Rather, the transnational exchanges and gainers activities spurred by fundamental freedoms narrow down the demand gaps between the diverging-subsets in due course. The descriptive and quantitative evidences together with analysis on legal-neofunctional embrace offered in this contribution are supportive of this premise. Direct taxation, an unspoken EU competence and a domain of high national politics, is also not impervious to integrative processes theorized by neofunctionalism. Instead of ascribing the limited steps towards tax harmonization to date as a failure, they need to be viewed in the wider context as a stage in the ongoing evolutionary process of EU political, legal and economic integration.

\section{References}

Aujean, M. (2007). The Future of Non-Discrimination: Direct Taxation in Community Law. In R. Avi-Yonah, J. Hines, \& M. Lang (Eds.), Comparative Fiscal Federalism: Comparing the Court of Justice and the US Supreme Court's Tax Jurisprudence (pp. 321-330). Alphen aan den Rijn: Kluwer Law International.

Cameron, D. (1998). Creating Supranational Authority in Monetary and Exchange-Rate Policy: The Sources and Effects of EMU. In W. Sandholtz, \& A. Stone Sweet (Eds.), European Integration and Supranational Governance (pp. 188-216). Oxford: OUP.

Caporaso, J., \& Keeler, J. (1995). The European Union and Regional Integration Theory. In C. Rhodes, \& S. Mazey (Eds.), The State of the European Union, Vol. 3, Building a European Polity? (pp. 29-62). Boulder, CO: Lynne Rienner.

Craig, P. (2002). The Evolution of the Single Market. In C. Barnard, \& J. Scott (Eds.), The Law of the Single European Market (pp. 1-39). Oxford: Hart Publishing.

Directorate-General of Taxation \& Customs \& Union (2015). CJEU Cases in the Area of, or of Particular Interest for, Direct Taxation. Retrieved from http://ec.europa.eu/taxation_customs/resources/documents/common/infringements/case_law/court_cases_di rect_taxation_en.pdf

Duncan, H., \& McLure, C., Jr. (1997). Tax Administration in the United States of America: A Decentralized System. Bulletin for International Fiscal Documentation, 51, 74-85.

Dyson, K., \& Sepos, A. (Eds.). (2010). Which Europe?: The Politics of Differentiated Integration. Basingstoke: Palgrave Macmillan.

Feld, L., \& Heckemeyer, J. (2011). FDI and Taxation: A Meta-Study. Journal of Economic Surveys, 25(2), 233272. http://dx.doi.org/10.1111/j.1467-6419.2010.00674.x

Garrett, G. (1992). International Cooperation and Institutional Choice: the European Community's Internal Market. International Organization, 46(2), 533-560. http://dx.doi.org/10.1017/S0020818300027806

Garrett, G. (1995). The politics of legal integration in the European Union. International Organization, 49(1), 171-181. http://dx.doi.org/10.1017/S0020818300001612 
Genschel, P., \& Jachtenfuchs, M. (2011). How the European Union Constrains the State: Multilevel Governance of Taxation. European Journal of Political Research, 50(3), 293-314. http://dx.doi.org/10.1111/j.1475-6765.2010.01939.x

Genschel, P., \& Schwarz, P. (2011). Tax Competition: A Literature Review. Socio-Economic Review, 9(2), 339370. http://dx.doi.org/10.1093/ser/mwr004

Genschel, P., Kemmerling, A., \& Seils, E. (2011). Accelerating Downhill: How the EU Shapes Corporate tax Competition in the Single Market. Journal of Common Market Studies, 49(3), 586-606. http://dx.doi.org/10.1111/j.1468-5965.2010.02136.x

Graetz, M. J., \& Warren, A. C. (2006). Income Tax Discrimination and Political and Economic Integration of Europe. Yale Law Journal, 115(6), 1186-1255. http://dx.doi.org/10.2307/20455654

Graetz, M. J., \& Warren, A. C. (2007). Dividend taxation in Europe: When the ECJ makes tax policy. Common Market Law Review, 44(6), 1577-1623.

Haas, E. (1958). The Uniting of Europe: Political, Economic and Social Forces, 1950-1957. Stanford, CA: Stanford University Press.

Haas, E. (1964). Beyond the Nation State: Functionalism and International Organization. Stanford, CA: Stanford University Press.

Hellerstein, W. (2008). Lessons of US Subnational Experience for EU CCCTB Initiative. In W. Schon, U. Schreiber, \& C. Spengel (Eds.), A Common Consolidated Corporate Tax Base for Europe (pp. 150-154). Heidelberg: Springer Verlag.

Keen, M. (2001). Preferential Regimes Can Make Tax Competition Less Harmful. National Tax Journal, 54(4), 757-762. http://dx.doi.org/10.17310/ntj.2001.4.04

Kemmeren, E. (2008). ECJ Should Not Unbundle Integrated Tax Systems! EC Tax Review, 17(1), 4-11.

Khan Niazi, S., \& Krever, R. (2016). An account of recent activity of the European Commission on applying state aid rules to income taxes: In retrospect and prospect. Taxation Law and Policy Research Group Working Paper Series WP 201603 01, Monash Business School. Retrieved from http://papers.ssrn.com/sol3/papers.cfm?abstract_id=2740269

Khan Niazi, S., \& Krever, R. (2015). Is integration of income taxation possible in the EU? Australian Tax Forum, $30(2), 455-470$.

KPMG. (2006). KPMG's Corporate Tax Rate Survey: An international analysis of corporate tax rates from 1993 to 2006. Retrieved from http://www.lib.uwo.ca/files/business/KPMGCorporateTaxRateSurvey.pdf

Kumar, M., \& Quin, Q. (2012). Globalization and Corporate Taxation. IMF Working Paper WP/12/252. Washington DC: IMF.

Leuffen, D., Rittberger, B., \& Schimmelfennig, F. (2013). Differentiated Integration: Explaining Variation in the European Union. Basingstoke: Palgrave Macmillan.

Marks, G., Hooghe, L., \& Kermit, B. (1996). European Integration from the 1980s: State-Centric v. Multi-Level Governance. Journal of Common Market Studies, 34(3), 341-378. http://dx.doi.org/10.1111/j.1468-5965.1996.tb00577.x

McLure, C. Jr. (2007). Understanding Uniformity and Diversity in State Corporate Taxation. National Tax Journal, 61(1), 141-159. http://dx.doi.org/10.17310/ntj.2008.1.07

McLure, C. Jr. (2008). Legislative, Judicial, Soft Law, and Cooperative Approaches to Harmonizing Corporate Income Taxes in the US and the EU. Columbia Journal of European Law, 14(1), 377-444.

Mintz, J. (2004). Corporate Tax Harmonization in Europe: It's All about Compliance. International Tax and Public Finance, 11(2), 221-234.

Moravcsik, A. (1993). Preferences and Power in the European Community: A liberal Intergovernmentalist

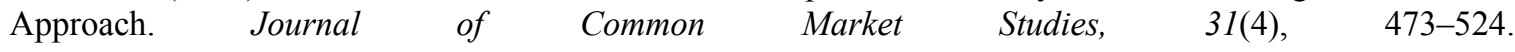
http://dx.doi.org/10.1111/j.1468-5965.1993.tb00477.x

Moravcsik, A. (1995). Liberal Intergovernmentalism and Integration: A Rejoinder. Journal of Common Market Studies, 33(4), 611-628. http://dx.doi.org/10.1111/j.1468-5965.1995.tb00554.x

Radaelli, C., \& Kraemer, U. (2008). Governance Areas in EU Direct Tax Policy. Journal of Common Market 
Studies, 46(2), 315-336. http://dx.doi.org/ 10.1111/j.1468-5965.2007.00778.x

Reimer, E. (2011). The Abolition of Article 293 EC: Comments on Hoffman's Analysis. In A. Rust (Ed.), Double Taxation within the European Union (pp.87-97). Alphen aan den Rijn: Kluwer Law International.

Roggeman, A., Verleyen, I., Van Cauwenberge, P., \& Coppens, C. (2015). Did the Economic Impact of a Common Consolidated Corporate Tx Base (CCCTB) Affect the Voting Behaviour of the Members of the European Parliament? De Economist, 163(1), 1-123. http://dx.doi.org/10.1007/s10645-014-9238-4

Sandholtz, W. (1993). Choosing Union: Monetary Politics and Maastricht. International Organization, 47(1), 139. http://dx.doi.org/10.1017/S0020818300004690

Sandholtz, W., \& Stone Sweet, A. (2013). Neo-functionalism and Supranational Governance. In E. Jones, A. Menon, \& S. Weatherill (Eds.), The Oxford Hand Book of the European Union. Oxford: Oxford Hand Books Online. http://dx.doi.org/10.1093/oxfordhb/9780199546282.001.0001

Sandholtz, W., \& Zysman, J. (1989). 1992: Recasting the European Bargain. World Politics, 42(1), 95-128. http://dx.doi.org/10.2307/2010572

Schaper, M. (2014a). 30 Years of Direct Tax Litigation before the Court of Justice of the European Union: An Empirical Survey. Bulletin for International Taxation, 68(4/5), 236-249.

Schaper, M. (2014b). A Computational Legal Analysis of Acte Clair Rules of EU Law in the Field of Direct Taxes. World Tax Journal, 6(1), 77-108.

Schimmelfennig, F., Leuffen, D., \& Rittberger, B. (2014). The European Union as a System of Differentiated Integration: Interdependence, Politicization and Differentiation. Political Science Series Working Paper No. 137. Vienna: Institute for Advance Studies (HIS).

Schon, W. (2015). Neutrality or Territoriality - Competing or Converging Concepts in European Tax Law? Bulletin for International Taxation, 69(4/5), 271-293.

Smith, S. (1996). Subsidiarity and neutrality in European tax policy: economic considerations. In S. Smith and R. Barents (Eds.), Neutrality and subsidiarity in taxation. London: Kluwer Law International.

Stone Sweet, A. (Ed.). (2004). The Judicial Construction of Europe. Oxford: OUP.

Stone Sweet, A., \& Sandholtz, W. (1997). 'European Integration and Supranational Governance', Journal of European Public Policy, 4(3), 297-317. http://dx.doi.org/10.1080/13501769780000011

Stone Sweet, A., \& Sandholtz, W. (1998). Integration, Supranational Governance, and the Institutionalization of the European Polity. In W. Sandholtz and A. Stone Sweet (Eds.), European Integration and Supranational Governance (pp. 1-26). Oxford: OUP.

Tizzano, A. (1981). The Powers of the Community. In A. Tizzano (Ed.) in Commission of the European Communities, Thirty years of Community Law (pp. 43-67). Luxembourg: Office of Official Publications of European Communities.

Wasserfallen, F. (2014). Political and Economic Integration in the EU: The Case of Failed Tax Harmonization. Journal of Common Market Studies, 52(2), 420-435. http://dx.doi.org/10.1111/jcms.12099

\section{Notes}

Note 1. Amongst limited instances of scholarship on European tax integration beyond national bargains, see, e.g., Genschel and Jachtenfuchs (2011), Radaelli and Kraemer (2008). The current work adds to similar scholarship and extends further in that this contribution: (1) explicitly employs the latest account of neofunctional tools theorized by Sandholtz and Stone Sweet (2013), (2) argues explicitly a legal-fiscal interplay under neofunctional integration processes and (3) provides insights on prospects for differentiated (tax) integration and neofunctional rationale.

Note 2. The pioneering substantive direct tax legislation was adopted in 1990; Council Directives 90/434/EEC and 90/435/EEC. An earlier tax legislation, adopted in 1977 (Council Directive 77/99/EEC) was largely meant for procedural matters rather than substantive issues of loss of any national taxing power with respect to elimination of double taxation in the single market.

Note 3. Council Directives 2003/48/EC and 2003/49/EC. The former was repealed on November 10, 2015 through Council Directive (EU) 2015/2060; the repeal was consequential to amendment in Directive 2011/16/EU as regards mandatory automatic exchange of information in the field of taxation. Recently, a momentum has 
been witnessed to adopt EU-level measures against base erosion and profit shifting besides a draft legislation on anti- avoidance directive. These developments, however, are under process and have yet to attain a final binding status; for details of complete "Anti- Tax Avoidance Package" presented by the European Commission, see http://ec.europa.eu/taxation_customs/taxation/company_tax/anti_tax_avoidance/index_en.htm.

Note 4. While fully acknowledging intergovernmental contribution to the European literature on fiscal integration, the current study seeks to assess a given dataset by employing neofunctional tools.

Note 5. TFEU: free movement of workers (Art. 45), goods (Art. 28), capital (Art. 63) and to provide services (Art. 56) together with right to establishment (Art. 49) across the Internal Market (Art. 26).

Note 6. In addition to legislation proposals and initiating proceedings against infringing national laws, host of other integration initiatives are also undertaken at the Commission-level including public consultations, workshops and working groups; see e.g., Sandholtz \& Stone Sweet (2013), Marks et al. (1996).

Note 7. COM(2011) 121/4 on CCCTB. The Commission announced its re-launch in press release of June 17, 2015. Retrieved from http://europa.eu/rapid/press-release_IP-15-5188_en.htm. To this end, public consultations initiated by the European Commission (on October 8, 2015) closed recently (on January 8, 2016); an updated and pragmatic CCCTB draft legislation is expected to be tabled around third quarter of 2016.

Note 8. Directives in notes 2, 3 .

Note 9. $\operatorname{COM}(2011) 712$ on double taxation in the single market.

Note 10. In practice, the new members however may not take as longer periods as taken by the founding members to attain tax-spillover (see Section 4.3); it is because the former essentially would not undergo the decades-demanding processes of constitutionlaization of EU law, strength achieved by EU organs, development of transnational interest groups, pro-integration lobbies, and so forth.

Note 11 . Poland slashed corporate tax-rate from $27 \%$ to $19 \%$, Slovak Republic $25 \%$ to $19 \%$ and Cyprus $28 \%$ to $15 \%$; for tax rates, see KPMG (2006).

Note 12. On how the time factor also plays potential role in shaping differentiated integration in European sub-systems, see notes 17,18 .

Note 13. See, e.g., the recent ECJ decisions (regardless of outcome) pursuant to Commission's infringement proceedings based on based on earlier Court rulings: Case C-172/13, Commission vs UK (of February 3, 2015) was consequence of an earlier court ruling in C-446/03, Marks \& Spencer; Case C-485/14, Commission v France (of July 16, 2015) was based on earlier Court ruling C-318/07, Persche. See also Commission's role in note 6.

Note 14. Findings on rise in gainers demand based solely on data of tax disputes at ECJ rather represent conservative estimate. Results can get more robust if one also adds Commission's infringement proceedings initiated against national tax provisions settled outside the ECJ; e.g., during the period 2000-2013, almost 700 infringement proceedings cases of the Commission on income taxation were settled out-of-court [Directorate-General of Taxation \& Customs Union's letter of January 29, 2015 (personal communication; letter on file with author)]. Likewise, if the Commission-level data of investigations and decisions on application of state aid rules to income and corporate taxes is also taken into account, it could further add robustness to the results on rise in gainers demand. On possibility of the Commission-level lobbying against tax-aid activity of distortionary character with implications to level-playing field in the common market, see, e.g., Khan Niazi \& Krever (2016: 16-18, note 55).

Note 15. In the founding times, the (then) six Member States, in their capacity as members of Organization for European Economic Cooperation (predecessor of Organization for Economic Cooperation and Development or OECD) were also contributory to the efforts to develop model tax convention; its outcome appeared on July 1, 1963 as an OECD Model Tax Convention; see Reimer (2011: 90). The OECD Model has since been widely adopted by the Member States as bilateral tools against cross-border double taxation.

Note 16. COM(2001) 260 on tax policy in the European Union - priorities for the years ahead.

Note 17. Generally also see Dyson and Sepos (2010) explaining variations in EU integration, in particular, chapters of the volume concerning differentiated integration triggered by temporal, functional and spatial factors.

Note 18. The data (based on Directorate-General Taxation \& Customs Union, 2015; Schaper, 2014a: 238-239) shows that out of the total tax disputes (around 290) referred to the ECJ during 1983-2014, tow-third (189 cases) relate to the six founding EU members, i.e., Germany, France, Italy, Netherlands, Belgium and Luxembourg.

Note 19. Ireland and the United Kingdom are the opt-outs of the Schengen law. 
Note 20. See, e.g., Arts. K.15, K.16 added to the Treaty on European Union (TEU) through the Amsterdam Treaty.

Note 21. On enhanced cooperation, see Arts. 43-45 TEU, added through the Treaty of Nice.

Note 22. Our focus of discussion here remains varied societal demand and potential secondary law-making. On discourse theorizing differentiated integration and neofunctionalism, see Leuffen, Rittberger \& Schimmelfennig (2013: 62-83).

\section{Copyrights}

Copyright for this article is retained by the author(s), with first publication rights granted to the journal.

This is an open-access article distributed under the terms and conditions of the Creative Commons Attribution license (http://creativecommons.org/licenses/by/3.0/). 